\title{
RISK PROPENSITY, TRUST, AND TRANSACTION COSTS IN RELATIONAL CONTRACTING
}

\author{
John K. Masters \\ Louisiana State University - Shreveport \\ Shreveport, LA \\ Grant Miles \\ Derrick D'Souza \\ University of North Texas \\ Denton, TX \\ John P. Orr \\ McKendree College \\ Lebanon, IL
}

\begin{abstract}
Critics of transaction cost economics (TCE) argue that TCE is not able to explain variations in governance arrangements between the extremes of market and hierarchy. They further dispute the assumptions of opportunism and risk neutrality underlying the theory. While TCE proponents have developed approaches that address each of these criticisms separately, we propose that combining the approaches to simultaneously address both challenges alters the nature of the predictions. We explore the roles of risk propensity and trust within a TCE framework. We then test the ability of these variables to predict variations in governance between the extremes of market and hierarchy.
\end{abstract}

The increasing prevalence of a broad class of organizational forms that are neither market nor hierarchy has challenged traditional notions of organizational relationships. Perhaps nowhere are these challenges more clearly seen than within the study of transaction cost economics (TCE) (Coase, 1937; Williamson, 1975). Critics have challenged both the market/hierarchy dichotomy that originally served as the foundation for TCE and the behavioral assumptions that underlie the theory.

In response to these challenges, researchers have proposed modifications to the basic TCE theory. Proposed adjustments include moving from a dichotomy to a continuum, where hybrids fall between the end points of market and hierarchies (Williamson, 1985; 1991), and the inclusion of behavioral variables as moderators within the model rather than as underlying assumptions (Chiles and McMackin, 1996). While each of these proposed modifications is built on a reasonable logic, there has been little, if any, empirical assessment of the 
predictions. More importantly, because each modification was proposed independently, the effect of concurrently including both of the modifications within the model has not been considered. When they are, the predictions of the model may be very different from what either would individually propose.

To help advance our understanding in this area, then, the current study includes trust and risk propensity in a TCE framework and examines their influence on the form of governance taken within a particular exchange relationship between firms. We begin by briefly reviewing TCE and its assumptions regarding opportunism, risk, and the role of trust. Next, we explore alternative ways that these concepts might be handled within a TCE context and develop hypotheses regarding the role of each of the variables. We then describe an empirical test of the hypotheses and discuss the results. A discussion of the implications of the results both for TCE in particular and for organizational forms in general concludes the paper.

\section{Literature Review}

In transaction cost economics (TCE), three characteristics of a given transaction are purported to influence the choice between market and hierarchical governance mechanisms: the need for transaction-specific investment, the likelihood of repetition, and uncertainty of performance (Coase, 1937; Williamson, 1975). As the level of each characteristic increases, the transaction becomes more likely to be governed using hierarchical rather than market governance mechanisms. Three assumptions regarding human nature are critical to this calculus. Bounded rationality addresses managerial behavior which is "intendedly rational, but only limitedly so" (Simon, 1961: xxiv). Under bounded rationality, decision makers do not possess or are not able to process complete information. Opportunism, defined as "self-interest seeking with guile" (Williamson, 1975: 26), requires not that all actors behave opportunistically, only that some do and that it is difficult or costly to determine which actors will behave opportunistically. Risk neutrality means that decision makers are indifferent between certain and uncertain returns as long as the expected value of the uncertain returns is equal to that of the certain returns over the longer term (Aoki, 1984).

\section{Modifications to TCE}

While a number of critics have challenged this traditional conception of TCE, the criticisms can be broadly grouped into two areas. The first group of critics challenge the behavioral assumptions underlying TCE. While the assumption of bounded rationality has not been challenged, both the notions of risk neutrality and opportunism have prompted considerable debate. That decision makers have variable risk preferences has been well established (e. g., Kahneman and Tversky, 1979; March and Shapira, 1992; Sitkin and Pablo, 1992). Further, these risk preferences have been shown to substantially influence decision outcomes (Sitkin and Pablo, 1992; Tversky and Kahneman, 1992). 
Even Williamson acknowledges that the risk preferences of decision makers, "for some purposes can be of utmost importance" (1985:389). He nevertheless adopts an assumption of risk neutrality in TCE.

Critics have also challenged TCE's underlying behavioral assumption of opportunism (Pratten, 1997). At a general level, these critics charge that trust is a more realistic characterization of economic actors than is opportunism (Bradach and Eccles, 1989; Granovetter, 1985; Hosmer, 1995). In this view, trust goes beyond simple self interest seeking and suggests a willingness to do business with a party even when that other party may be in a position to take advantage. Williamson (1993) has argued that the social relations necessary to produce such trust are likely to be found only in very close personal relationships and not in economic exchange. There is, however, at least some empirical evidence to suggest that trust goes beyond self-interest and is in fact found in economic relationships (Tyler and Degoey, 1996). Other researchers have shown that trust can change perceptions regarding opportunism (Nooteboom, Berger, and Noorderhaven, 1997).

Chiles and McMackin (1996) have suggested that both risk propensity and trust can be handled within a TCE framework. They proposed that, rather than treating these variables as underlying behavioral assumptions, trust and risk propensity may actually serve as moderators of the relationship between TCE variables and governance mechanisms. They argued that markets work as a governance mechanism because, in the face of opportunistic behavior, either party to the transaction can switch to another transaction partner. The need for transaction specific investment, though, creates a condition of small numbers bargaining. Having invested in assets specific to the exchange, at least one of the parties involved cannot walk away from the deal and revert to a free market exchange without giving up some part of the value of those investments. This condition, in turn, increases the risk of opportunistic behavior by the other party and brings pressure to internalize the transaction by moving from the market to a hierarchy governance structure. This risk of opportunistic behavior resulting from transaction specific investment links TCE with both risk propensity and trust.

Speaking particularly to the case of asset specificity, Chiles and McMackin (1996: 82) presented a model showing that the level of asset specificity necessary to trigger the shift from market to hierarchy would be higher for those firms whose managers are risk seeking and lower for those firms whose managers are risk averse (the common notion of risk neutral managers falls in between these extremes). Similarly, they posited that increasing levels of trust would further increase the level of asset specificity necessary to bring about the shift from market to hierarchy. This conceptualization, though, is predicated on TCE's original view of governance as a choice between market or hierarchy. A second group of critics have challenged this view.

Critics of this polarization of governance into a dichotomy of markets and hierarchies (e.g., Hennart, 1993; Noorderhaven, 1994; Robins, 1987) note 
that many transactions are governed neither by market nor by hierarchy, but rather reflect characteristics of both forms. These hybrid forms have proven to be relatively stable over time (Eccles, 1981). Studies in support of TCE (e.g., Klein, Crawford and Alchian, 1978; Masten, Meehan and Snyder, 1989; Monteverde and Teece, 1982; Walker and Weber, 1984), the critics assert, are unable to explain differences in the levels of integration between firms (Hennart, 1993; McWilliams and Gray, 1995). The critics view as a central failing of TCE its apparent inability to account for multiple organizational forms to govern seemingly similar transactions.

To address the challenge of organizational form, TCE theorists have introduced the notion of hybrid transactions into the governance model, making the pure market and the pure hierarchy the extremes of a continuum (Williamson, $1985,1991,1999)$. Hybrid transactions are based on the notion of relational governance, in which the formal contract serves as a framework for development of a long-term relationship (Heide, 1994; Macneil, 1978, 1980; Williamson, 1985,1991 ). The concept of quasi-integration (Blois, 1972; McWilliams and Gray, 1995) has proven useful in viewing TCE as a continuum. Quasi-integration refers to the strength of ties between firms. The ties between firms may be stronger, resembling a hierarchy, or weaker, as expected under market governance. The strength of these ties is thought to be predicted by the same transaction characteristics posited in the traditional TCE model.

\section{Risk and Trust in Relational Contracting}

The proposals set forth by Williamson $(1985,1991,1999)$ and by Chiles and McMackin (1996) both present interesting ways of addressing the challenges to TCE. Each of these arguments, however, deals with one of the criticisms of TCE while ignoring the other. On the surface, combining the proposals would appear to be a straightforward task since Williamson's modification alters the outcome variable while Chiles and McMackin's proposals focus on the inclusion of moderators. As asset specificity increases, firms would move from market governance into hybrid arrangements and, at sufficiently high levels of asset specificity, into a formal hierarchy. Such movement would be moderated, though, by the risk propensity of the managers involved in the decisions and the level of trust they have in their partners.

Incorporating the view of TCE as a continuum, though, changes the logic on which Chiles and McMackin (1996) based their propositions. They argued that markets work as a governance mechanism because the ability to act opportunistically is vitiated by the threat that the parties to the transaction can freely switch to a different transaction partner. The need to invest in transaction-specific assets limits this ability to switch by creating a condition of small numbers bargaining. Consequently, firms move to hierarchical governance under conditions of high transaction-specific investment.

In relational contracting, though, this movement creates a conundrum. Firms move toward hierarchical governance without moving to hierarchical gover- 
nance. By creating close ties with a transaction partner, the parties have limited the power of the market to govern the transaction. They have not, however, entered the safety of hierarchical governance until they truly integrate, creating a superordinate authority. Ring and Van de Ven (1994) built on Social Comparison Theory (Kelly and Thibault, 1959) to contend that close inter-organizational relationships foreclose opportunities for developing alternative relationships, thereby limiting the power of the market to govern exchange.

This foreclosure of alternatives comes from the nature of relational contracting. Relational contracting differs from both market contracting and authoritybased (hierarchical) governance. Market contracting is characterized by clear, complete, essentially simultaneous exchange. Since no future transactions influence the exchange, the parties reach agreement based on an evaluation of the equality of exchange in the current transaction (Macneil, 1980; Ring and Van de Ven, 1992).

Relational contracting, in contrast, does not anticipate that the individual transaction is complete in itself. Relational contracts anticipate a series of uncertain, open-ended, incomplete exchanges over a moderate to long term. The relational contract is evaluated based on equity rather than equality. At any given time, one party may have given more than they have received (Macneil, 1980; Ring and Van de Ven, 1992). Constant monitoring to see which party is ahead in the game can undermine the relational contract. In a longitudinal study of several inter-organizational relationships, Van de Ven and Walker (1984) found that excessive monitoring and the use of formal safeguards led to distrust among the parties and increased the likelihood that the relationship would be severed.

Over time, the transactions become more socially embedded and informal psychological contracts increasingly substitute for formal contractual safeguards. "Investments include not only economic and technological resources of participating firms, but also social commitments and entanglements of individual agents" (Ring and Van de Ven, 1994: 106). Moreover, these commitments tend to persist in spite of growing inefficiencies or escalating risks associated with the relationship. A longitudinal study of three inter-organizational relationships that were showing increasingly poor results supported the social embeddedness effect. Despite the increasing evidence of the failure of the relationships, none of the parties took steps to end the relationships. In each case, the eventual termination required the intervention of outsiders not previously associated with the relational contract (Van de Ven, et. al., 1989). As Granovetter (1985) noted, the emergence of trust does not guarantee trustworthy behavior and may even increase the potential for opportunistic behavior.

By choosing a relational form, then, firms create their own condition of small numbers bargaining. We propose that this movement increases the risk of opportunism. In relational contracting, where close ties with a single transaction partner are developed without entering the safety of the hierarchy, the parties put themselves at greater risk of opportunistic behavior by their transaction 
partners. This risk would increase as the firms developed closer ties until the firms truly integrated their operations. The result of this movement can be pictured as a kinked risk curve (see Figure 1).

\section{Figure 1 \\ The Kinked Risk Curve}

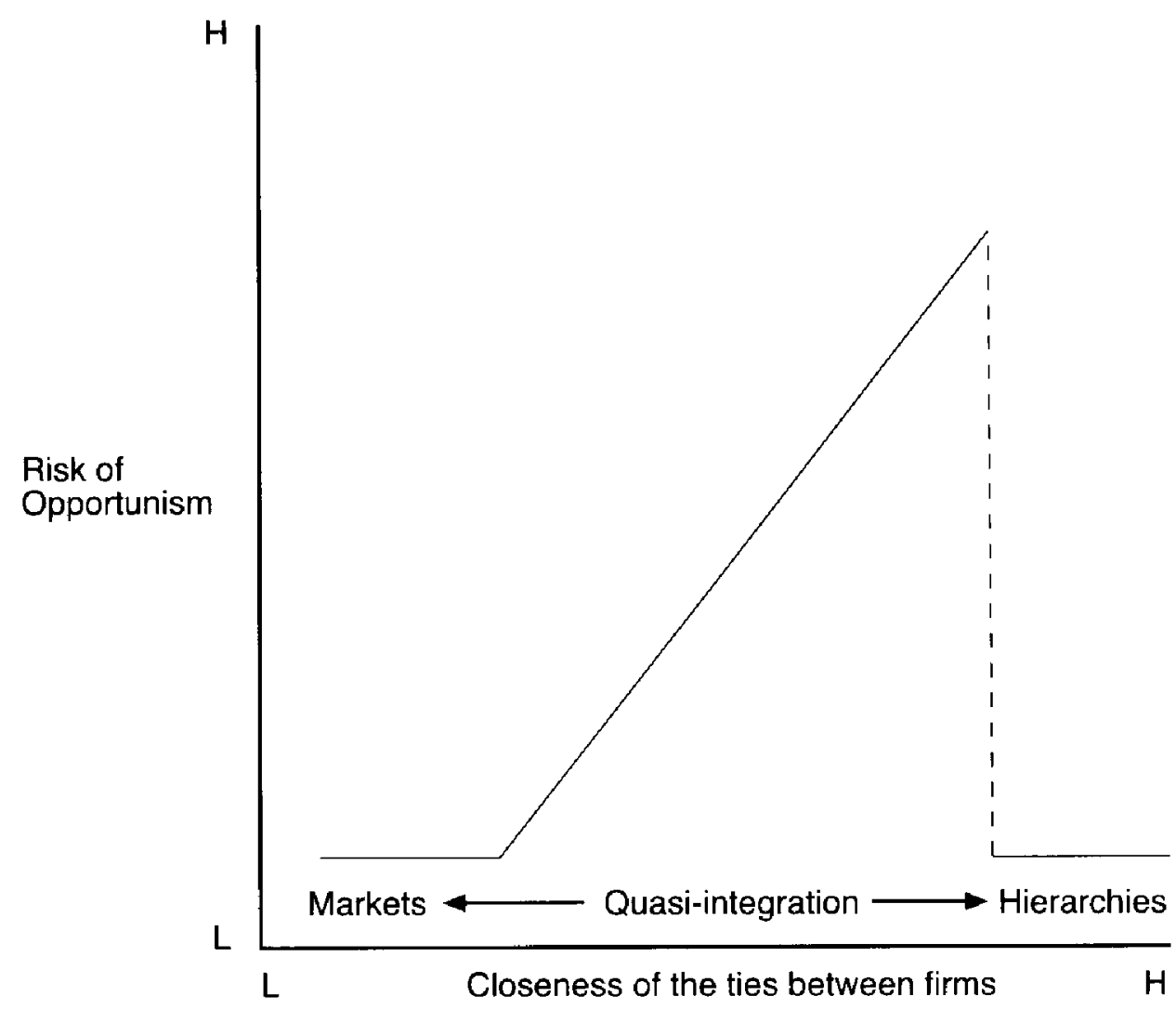

The predictions of Chiles and McMackin (1996) that applied to the pure market and the pure hierarchy would not hold true for the hybrid forms occupying the middle ground. The contrast between this new view of TCE in hybrid relationships and the previous views of TCE from which it is derived are depicted in Figure 2. Figure 2a depicts the traditional TCE view of asset specificity, with risk neutrality and opportunism assumed. Figure $2 b$ incorporates the views of Chiles and McMackin (1996) where risk propensity and trust function as moderators that decrease the likelihood that firms will switch from market to hierarchy in the face of transaction specific investment. The impact of combining the Chiles and McMackin model with the view of TCE as a continuum is shown in Figure $2 \mathrm{c}$. Here, the increased risk of opportunism resulting from developing close ties with a single transaction partner is illustrated as a feedback loop. By choosing closer ties with a single transaction partner, the firms create a condition of small numbers bargaining, thereby exposing themselves to an increased potential for 
opportunistic behavior. Consequently, decision makers with a higher tolerance for risk, or who have higher levels of trust in their partners, would be more willing to develop close ties with those partners.

Figure 2

The Evolution of Transaction Specific Investment, Risk Propensity and Trust in TCE

Figure 2a: Traditional View

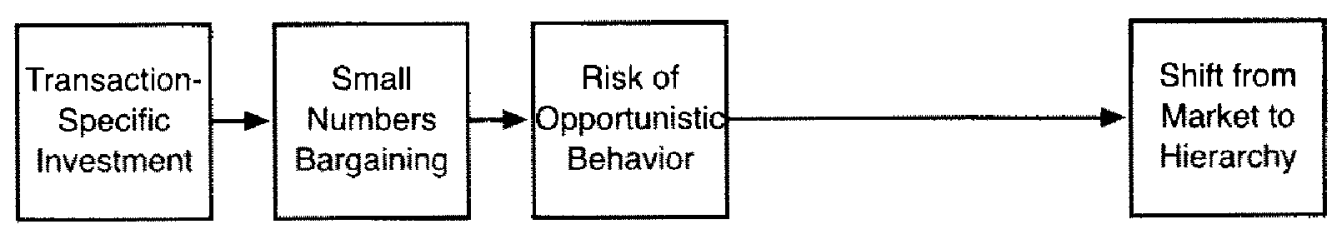

Figure 2b: Chiles and McMackin's (1996) View
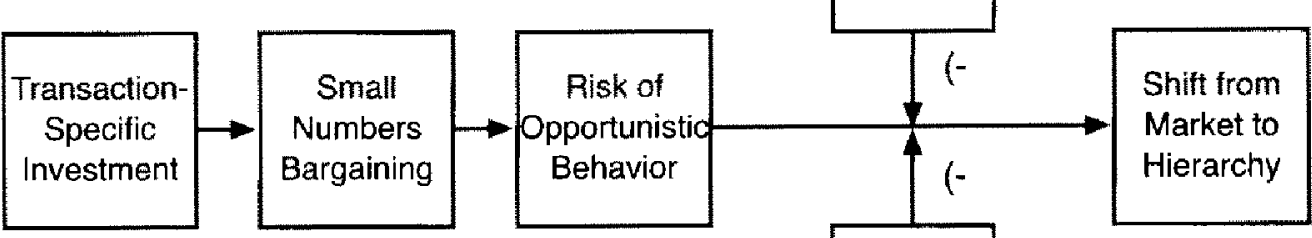

Risk

Tolerance

Figure 2c: The Impact of Risk and Trust in Relational Contracting

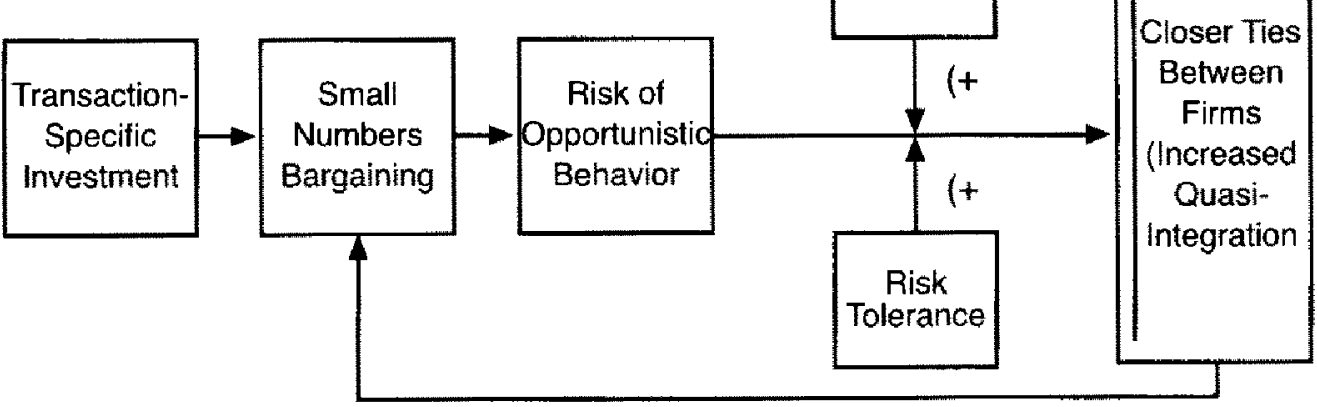

Formalizing the predictions of this third model (Figure $2 \mathrm{c}$ ) is now a straightforward matter. Ignoring for the moment the impact of risk propensity and trust, the straight-line portion of the model applies the traditional TCE logic to the case of relational contracting. Here, higher levels of each of the three TCE variables are associated with increased levels of quasi-integration. That is: 
Hypothesis 1: Firms will develop closer ties as the levels of asset specificity, likelihood of repetition, and uncertainty increase.

As shown in the model, however, these relationships may be moderated by the risk propensity of the decision maker. In keeping with Chiles and McMackin (1996), we formally address only the case of asset specificity. Hypothesis 1 suggests that increased asset specifity will lead to closer ties between firms. These closer ties between firms, though, feed back into the model to exacerbate the small numbers bargaining problem and increase the risk of opportunism. Now, the decision makers are assessing the level of risk associated with developing closer ties as well as the risk associated with asset specificity. Contrary to Chiles and McMackin's (1996) proposition, the preceding argument suggests that, at a given level of asset specificity, risk seeking managers will be more likely rather than less likely to develop close ties with their partners while risk averse managers will be more likely to retain the safety of the market as a fall back position. Thus, we predict that:

Hypothesis 2: Risk seeking decision makers will choose closer ties for their firms at a given level of asset specificity than will risk averse decision makers.

In addition to the moderating effect of variable risk preferences, decision makers also bring pre-existing feelings regarding trust to the table when determining the choice of governance mechanism for any given transaction. It has been argued that trust can be seen as offsetting the perceived risk of opportunism. That is, the more one trusts the transaction partner, the less concern there is about the partner behaving opportunistically (Nooteboom, Berger, and Noorderhaven, 1997). Consequently, a higher level of trust in the transaction partner should lead, ceteris paribus, to a greater willingness to adopt governance structures that might increase the potential for opportunism. Said more formally:

Hypothesis 3: Firms whose decision makers have a high level of trust in their transaction partners will develop closer ties at a given level of asset specificity than will firms whose decision makers have a low level of trust.

\section{Methods}

To test these hypotheses, we investigated motor carrier-shipper logistic alliance relationships. Logistics alliances are hybrid relationships that focus on the interface between the motor-carrier and the shipper who coordinates logistics (Bowersox, 1990; Gentry, 1996). They focus not just on the transac- 
tion at hand, but rather on building a relationship in which transactions can take place. As such, these alliances provide a particularly fertile ground for the current investigation.

We received permission from the Council of Logistics Management to use their national-level membership list of 13,000 members to select key informants for the study. Based on preliminary power analyses, we mailed a questionnaire following the principles outlined in Alreck and Settle (1995) and Dillman (1978) to operations managers in 1,260 firms (630 carriers and 630 shippers) randomly selected from the membership list. Of the 1,260 firms receiving the questionnaire, 324 returned usable replies - a response rate of $24.9 \%$.

Where possible, we selected measures that had been tested and validated in previous research. Except as otherwise noted, all the measures used 7 point Likert-type scales, with multiple items in each scale reverse-coded. Higher scores indicate higher levels of the construct.

\section{Independent Variables}

Asset specificity represents the extent to which assets involved in a transaction can be shifted to an alternate use without loss of value. We measured asset specificity using the Ego Asset Specificity Scale developed by Nooteboom and his colleagues (Nooteboom, et. al., 1997). In this scale, respondents evaluate the extent to which assets could be converted to alternate uses without reducing their productive capacity. Confirmatory factor analysis revealed the expected four dimensions. Reliability analysis of the four sub-scales, however, indicated an inter-subscale reliability of .78 and an overall reliability of .83. Consequently, we elected to use an average of the scale items as a single entry in the study.

Williamson (1985) conceptualized uncertainty as performance ambiguity, the degree to which one party to a transaction can monitor the contracted performance of the other party. For this study, uncertainty was measured using the mean of the four-item Performance Ambiguity Scale developed by Heide and Miner (1992). Respondents are asked to evaluate their firm's ability to assess performance in terms of direct supervision, standardized inputs, standardized processes, and standardized outcomes. This measure loaded on the expected single factor and showed an acceptable reliability $(\alpha=.72)$.

Following Zaheer and Venkatraman $(1994,1995)$, we used the duration of the logistics alliance in months as a proxy for likelihood of repetition. Ample evidence exists for the view that past experience relates to future likelihood of repetition (Heide and Miner, 1992). For example, Heide and John (1990) and Parkhe (1993) found historical length of relationship to be a significant indicator of intent to continue purchasing alliances.

\section{Moderator Variables}

Chiles and McMackin (1996) define risk propensity as the tendency of a manager to be either risk averse, risk neutral, or risk seeking in dealing with 
risk situations. Drawing on the work of MacCrimmon and Wehrung (1986), we developed a five item risk propensity scale for a logistics-alliance context. Factor analysis of data from a pilot-test of the questionnaire produced a twofactor measure of risk propensity which we labeled pre-decision risk propensity and post-decision making risk perceptions. Factor analysis of the risk items in the final data set also indicated a two-factor solution, with reliability levels of .61 and .51 respectively. These sub-scales appear to be measure two different constructs (inter-sub-scale reliability $=.18$ ). Given its higher reliability and our focus on the a priori choice of structure and process, we elected to use the trait measure of pre-decision risk propensity in the study. We coded the items such that higher scores indicate risk seeking while lower scores indicate risk aversion.

We measured trust using the 12-item Organizational Trust Inventory developed by Cummings and Bromiley (1996). This scale was originally developed using the theoretical underpinnings of TCE as applied to interorganizational relationships (Bromiley and Cummings, 1995). In this scale, respondents evaluate the focal partner in terms of three areas of trust (negotiates honestly, keeps commitments, and avoids opportunism). A reliability analysis of the three sub-scales of the instrument revealed acceptable reliability levels for all three of the theorized sub-scales and an inter-sub-scale reliability of .77. We entered the sum of the trust scale as a single variable in the study.

\section{Dependent Variables}

The closeness of the relationship in a hybrid governance arrangement has been conceptualized as having two dimensions: structure and process (Macneil, 1980; Williamson, 1985; Zaheer and Venkatraman, 1995). Structure is the extent to which two firms link their systems in ways that approximate integration in hierarchical relationships. In our study, structure was operationalized as the extent of electronic integration (the percentage of shipper-carrier transactions within the logistics alliance which take place via on-line data exchange or remote access to each other's computers). This measure is consistent with operationalizations by Zaheer and Venkatraman (1994) in the insurance industry and Venkatraman and Christiaanse (1996) in the airline industry.

Process, which focuses on the extent to which firms act together, was measured using the arithmetic mean of the three-item joint-action scale developed by Heide and Miner (1992) and used to good effect in Zaheer and Venkatraman's work (1995). Confirmatory factor analysis of the joint-action survey data revealed the theorized single dimension. While structure and process are viewed as separate dimensions, higher levels of either dimension should relate to governance structures more closely resembling hierarchical integration.

\section{Control Variables}

This study controlled for two situation-specific characteristics: differences due to industry and differences between the responses of shippers versus carriers. 
Industry has often been used in alliance studies as a control variable (Maltz, 1994; Parkhe, 1993). We operationalized industry as the primary, two-digit Standard Industrial Classification (SIC) of the shipper (e.g., Heide and John, 1990; Maltz, 1994). This control variable did not prove significant in the present study, though, and was omitted from the final analysis.

Since we were examining both parties to the transaction, we also controlled for any differences in the responses of shippers versus those of carriers in the study. We coded each respondent as 0 (for shippers) or 1 (for carriers). These differences proved significant with respect to the measures of governance and we included this control variable in the final models.

Finally, we asked the respondents to rate their relationship with the focal shipper or carrier according to three descriptions of alliances developed by Bowersox (1990). The least closely allied firms were described as having agreed to work together, but had not made any changes in their day-to-day operations. The most closely allied firms were those in which the parties had formed a true logistics alliance. In the analysis that follows, we excluded the middle form in order to heighten the differences between firms. However, we also conducted the analyses with all three forms. The results were not different in significance level or direction, but the $\mathrm{R}^{2}$ for all models was lower.

\section{Results}

Following adjustments for non-usable replies, the survey yielded a net overall response rate of 24.9 percent. The 324 responding firms represented a broad range of locations and industries, with 39 states and 41 different two-digit SICs represented in the data set. The years of employment with the firm of the key informants ranged from one to 37 years, with an overall mean of 10.4 years. To assess the likelihood of nonresponse bias influencing the results, we compared the results for early responders with those of late responders (Armstrong and Overton, 1977). The comparison revealed no significant differences between the two groups.

Table 1 contains the means, standard deviations and correlations for the variables in the study. The significant correlations were generally consistent with our hypotheses and with previous conceptualizations of the relationships between the constructs. Each of the TCE variables was significantly correlated with both dimensions of governance, as was risk propensity. Also as hypothesized, risk propensity was significantly correlated with asset specificity. Contrary to our expectations, though, trust was not significantly correlated with either governance dimension or with asset specificity, but was significantly positively correlated with both uncertainty and likelihood of repetition.

To test the hypotheses, we conducted regression analyses on the two dependent variables. The results of these regressions are presented in Table 2 (for the structure measure) and Table 3 (for the process measure). The body of each table presents standardized beta coefficients with asterisks indicating significant 
Table 1

Means, Standard Deviations and Correlations

\begin{tabular}{|c|c|c|c|c|c|c|c|c|c|}
\hline Variables & Mean & $\begin{array}{l}\text { Standard } \\
\text { Deviation }\end{array}$ & $\begin{array}{l}\text { Carrier or } \\
\text { Shipper? }\end{array}$ & Duration & Uncertainty & $\begin{array}{c}\text { Asset } \\
\text { Specificity }\end{array}$ & $\begin{array}{c}\text { Risk } \\
\text { Propensity }\end{array}$ & Trust & $\begin{array}{c}\text { Electronic } \\
\text { Integration } \%\end{array}$ \\
\hline Carrier or Shipper? & .46 & .50 & 1.000 & & & & & & \\
\hline Duration & 64.49 & 70.84 & .077 & 1.000 & & & & & \\
\hline Uncertainty & 4.33 & .91 & .050 & .014 & 1.000 & & & & \\
\hline Risk Propensity & 42.91 & 21.84 & $-346(* *)$ & .052 & .058 & $.122(*)$ & 1.000 & & \\
\hline Trust & 5.39 & .93 & .087 & $.123\left(^{*}\right)$ & $.256\left(^{* *}\right)$ & .053 & .030 & 1.000 & \\
\hline Electronic Integration \% & 42.82 & 39.74 & -.096 & $.160(* *)$ & $.138\left(^{*}\right)$ & $.151\left(^{* *}\right)$ & $.270\left(^{* *}\right)$ & .021 & 1.000 \\
\hline
\end{tabular}

$\mathrm{N}=324$

* Correlation is significant at the 0.05 level

** Correlation is significant at the 0.01 leve 
Table 2

Results of Regression for Structure (Electronic Integration \%)

(Values in cells are standardized beta coefficients)

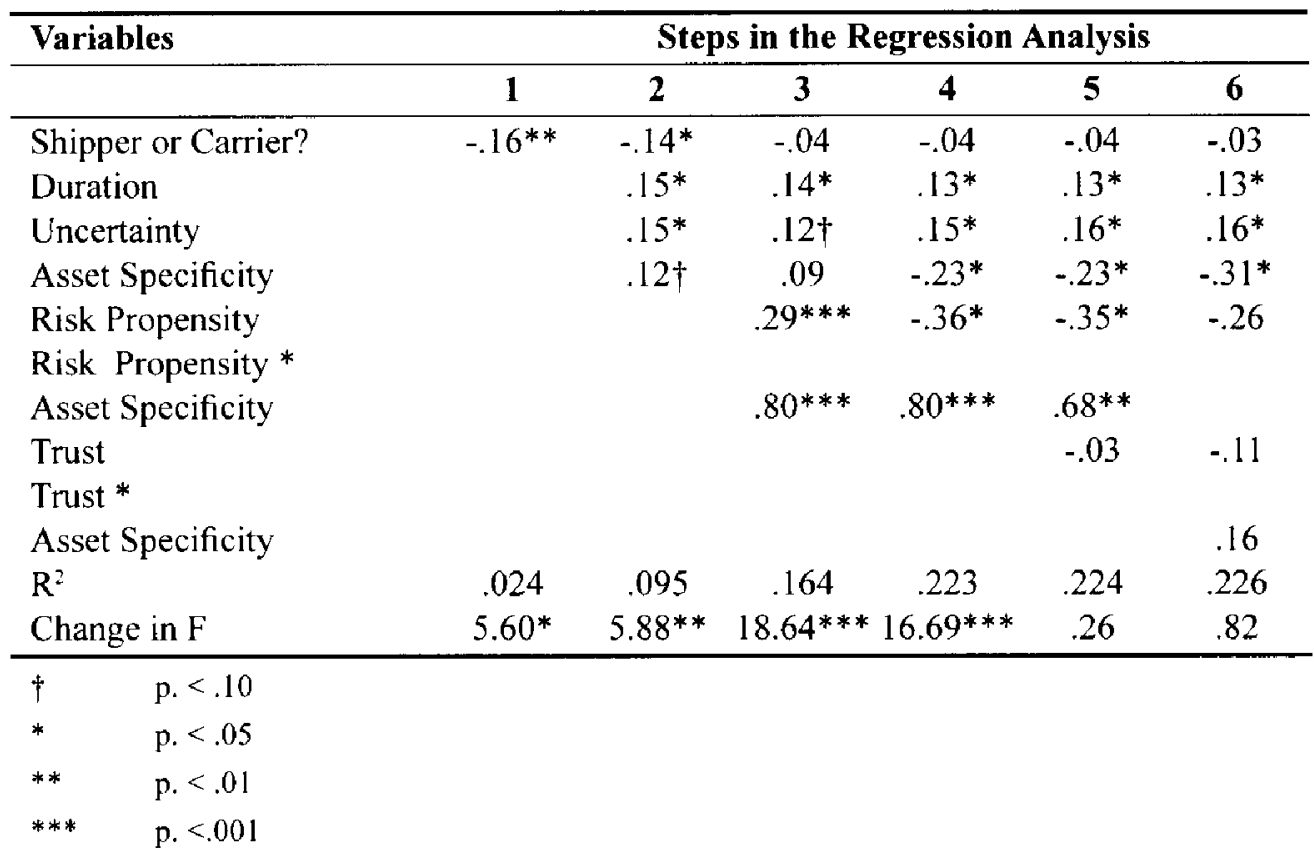

Table 3

Results of Regression for Process (Joint Action)

(Values in cells are standardized beta coefficients)

\begin{tabular}{|c|c|c|c|c|c|c|}
\hline \multirow[t]{2}{*}{ Variables } & \multicolumn{6}{|c|}{ Steps in the Regression Analysis } \\
\hline & 1 & 2 & $\mathbf{3}$ & 4 & 5 & 6 \\
\hline Shipper or Carrier? & $-.26 * * *$ & $-.26 * * *$ & $-.25 * * *$ & $-.25 * * *$ & $-.26 * * *$ & $-.25^{* * *}$ \\
\hline Duration & & .07 & .07 & .06 & .05 & .06 \\
\hline Uncertainty & & $.27 * * *$ & $.27 * *$ & $.29^{* * *}$ & $.27 * * *$ & $.27 * * *$ \\
\hline Asset Specificity & & $.14^{*}$ & $.14^{*}$ & -.06 & -.06 & -.17 \\
\hline Risk Propensity & & & .04 & $-.35^{*}$ & $-.37^{*}$ & -.23 \\
\hline \multicolumn{7}{|l|}{ Risk Propensity* } \\
\hline Asset Specificity & & & $.49 * *$ & $.49^{* *}$ & .32 & \\
\hline Trust & & & & & .07 & -.04 \\
\hline \multicolumn{7}{|l|}{ Trust * } \\
\hline Asset Specificity & & & & & & .24 \\
\hline $\mathrm{R}^{2}$ & .069 & .190 & .192 & .213 & .218 & .224 \\
\hline Change in $\mathrm{F}$ & $17.47 * * *$ & $11.56 * * *$ & .38 & $6.27^{*}$ & 1.43 & 1.84 \\
\hline p. $<.10$ & & & & & & \\
\hline p. $<.05$ & & & & & & \\
\hline p. $<.01$ & & & & & & \\
\hline p. $<.001$ & & & & & & \\
\hline
\end{tabular}


effects. In both tables, the focus is on steps 2,4 , and 6 , which represent each of the three hypotheses respectively.

\section{Structure}

The initial regression focused on structure as the dependent variable. In step 2 of this analysis, we added the variables derived from the TCE perspective to the control variable entered in step one. The addition of the TCE variables did result in a significant change in the $F$ statistic $(p .<.01)$, but showed a relatively low $R^{2}$ of .095 . Both likelihood of repetition and uncertainty were significant predictors of electronic integration ( $p .<.05$ ). Asset specificity, though functioning in the predicted direction, was only significant at a relaxed level (p. $<.10$ ).

In step 4 of the analysis, we tested the interaction between risk propensity (entered in step 3 ) and asset specificity as a predictor of electronic integration between firms. The change in $F$ was again significant $(p .<.001)$ and the variance explained by the model increased substantially $\left(\mathrm{R}^{2}=.223\right)$. More importantly, the interaction term was significant (p. $<.001)$ and in the predicted direction. Further examination of the interaction confirmed an interpretation in line with our predictions. Firms which were risk seeking were more closely quasi-integrated at a given level of asset specificity than were risk averse firms. Taken together, these results support the view of risk propensity as a moderator of the relationship between asset specificity and the strength of the ties between firms (hypothesis 2).

The remaining steps in Table 2 did not support the third hypothesis. The addition of trust and its interaction with asset specificity did not influence the relationships seen in the earlier models. Duration, uncertainty, asset specificity, and risk propensity remained significant, but the model's predictive ability was not enhanced by the addition of the remaining variables. It is also interesting to note that in both step 4 and step 6 asset specificity and risk were both significant predictors but the sign of each was reversed from what it had been in previous models. While it is tempting to speculate as to the meaning of this, we take a conservative approach and assume that the presence of the interaction term makes interpretation of individual terms problematic.

\section{Process}

The results of the regression with respect to process, presented in Table 3, are similar to those for structure. Uncertainty, asset specificity, and the interaction of risk propensity with asset specificity were all significant predictors of joint action, the measure of process quasi-integration. For process, however, we found no significant effect for likelihood of repetition in the model. Analysis of the interaction showed the same pattern as with structure. There was a significantly more positive association between asset specificity and process for high risk propensity decision makers than for low risk propensity decision makers. Again, trust had no significant effect. 
Viewing the results of both regressions together, we see support for Hypotheses 1 and 2. In each model, the interaction of risk propensity with asset specificity was significant and in the predicted direction. Trust was not significant in either model, however, so Hypothesis 3 was not supported.

\section{Discussion and Conclusion}

The results presented above provide general support for TCE as a predictor of the closeness of the ties between firms. Treating risk propensity and trust as important variables in the process rather than as underlying assumptions, though, adds a new dimension to the analysis. We examined the influence of these variables in the context of relational contracting rather than in the discrete choice between market or hierarchy. Contrary to the predictions of Chiles and McMackin (1996) that focused on the discrete choices, we posited that relational contracting would add an additional risk of opportunism and thus higher risk propensities would be necessary for closer ties between firms to develop at a given level of asset specificity. In the present study, firms with risk seeking decision makers did exhibit closer ties with their alliance partners at a given level of asset specificity than did firms with risk averse decision makers. These findings are consistent with our contention that the risk of opportunism in relational contracting comes not just from transaction-specific investment, but from the organizational form itself.

The findings regarding risk propensity also raise serious questions regarding the conceptualization of TCE governance mechanisms as a linear continuum. If hybrid relationships actually fall on a linear continuum between markets and hierarchies, such findings would not be expected. Instead, one would expect to see a pattern in which there was a consistent influence of variables across the continuum. We introduced the notion of a kinked risked curve depicted in Figure 1 as a possible alternative logic to that of Chiles and McMackin. With the inclusion of risk propensity, the influence of transaction specific investment differs not only in strength but also in direction as firms develop closer and closer ties. Rather than driving firms away from developing close ties, risk seeking decision makers do appear to select closer ties. Our findings suggest that TCE variables do serve as predictors of the governance structure chosen. The addition of risk preferences into the model, however, indicates that the influence of the TCE variables may differ depending on the level of risk that decision makers are willing to assume and, in the case of hybrids, on risks associated with the governance choice itself.

While such a notion is intriguing and clearly worthy of further study, we would urge some degree of caution in generalizing these results. We cannot claim to have tested the notion of a kinked risk curve. Our focus in this study was on TCE's ability to predict the finer-grained distinctions between levels of quasi-integration in relational contracting. Other research has supported TCE's ability to predict the extremes of market and hierarchy and our sample 
did not include those extremes. Further testing of this notion which includes the full range of organizational relationships from market to hierarchy would be informative. The role of these behavioral variables, if any, in the extreme forms remains untested.

The current study focused on shipper-carrier logistics alliances and the relationships found here may not be found in other hybrid arrangements. Vertical integration through the rent chain represents only a fraction of the purposes behind hybrid arrangements. Whether these findings would hold true for other sorts of alliances (e.g., those initiated for the purpose of knowledge creation or transfer) remains to be seen. That said, logistics alliances seemed particularly fertile ground for study since they represent a hybrid form in which distinct firms develop relatively enduring relationships. Further, these alliances have been viewed as relational in nature, with an emphasis on interorganizational trust. Still, many other hybrid forms will need to be examined.

The role of trust in the choice of organizational relationship also requires further specification. Our contention that trust would further moderate the closeness of ties between firms was not supported in the present research. We did, however, see significant positive correlations between trust and likelihood of repetition and between trust and uncertainty. Bradach and Eccles (1989) proposed that trust may represent a separate governance mechanism distinct from the price and authority mechanisms of market and hierarchy. They viewed markets as being governed by price, hierarchies by authority mechanisms, and posited that trust would represent a third governance mechanism. Ouchi (1980) used the term clans to describe this third governance choice. The pattern of correlations we found would be consistent with that view.

It would also be useful to examine these relationships over time. In addition to the standard disclaimers about correlation and causality, the effect of duration on trust bears consideration. Work by Sitkin and Pablo (1992) and Sitkin and Weingart (1995) has suggested that, under conditions of high performance ambiguity, repeated positive experiences with a transaction partner increase perceptions of trust. The pattern of correlations we found would be consistent with that view as well.

The current research clearly represents a beginning rather than an end. While we believe the results of this study add considerably to our understanding of organizational relationships, the precise relationships between TCE, risk propensity, and trust remain to be explained. Still, the present study, with its emphasis on the role of risk in relational contracting, suggests a very different view of the mechanisms used to organize transactions from that in the literature to date. We encourage future research to focus both on replicating these findings in other contexts and on furthering our understanding of the precise mechanisms driving this process. 


\section{References}

Alreck, P. L. \& Settle, R. B. (1995). The survey research handbook. (2d ed.). Chicago: Irwin.

Armstrong, J. S. \& Overton, T. S. (1977). Measuring nonresponse bias in mail surveys. Journal of Marketing Research, 14, 396-402.

Aoki, M. (1984). The cooperative game theory of the firm. New York: Oxford University Press.

Blois, K. J. (1972). Vertical quasi-integration. Journal of Industrial Economics, 20, 252-272.

Bradach, J. L. \& Eccles, R. G. (1989). Price, authority, and trust: From ideal types to plural forms. Annual Review of Sociology, 15, 97-118.

Bowersox, D. J. (1990). The strategic benefits of logistics alliances. Harvard Business Review, 68, 4, 36-45.

Bromiley, P. \& Cummings, L. L. (1995). Transaction costs in organizations with trust. In R. Beis, B. Sheppard, \& R. Lewicki (Eds.) Research on Negotiations in Organizations, 5, 219-247.

Chiles, T. H. \& McMackin. J. F. ( 996 ). Integrating variable risk preferences, trust, and transaction cost economics. Academy of Management Review. 21, 73-99.

Coase, R. H. (1937). The nature of the firm. Economica, 4, 386-405.

Cummings, L. L. \& Bromiley, P. (1996). The Organizational Trust Inventory (OTI): Development and validation. In R. M. Kramer \& T. R. Tyler (Eds.) Trust in organizations. (pp. 302-329). Thousand Oaks, CA: Sage.

Dillman, D. A. (1978). Mail and telephone surveys: The total design method. New York: Wiley.

Eccles, R. (1981). The quasi-firm in the construction industry, Journal of Economic Behavior in Organizations, 2, 335-357.

Gentry, J. J. (1996). The role of carriers in buyer-supplier strategic partnerships: A supply chain management approach. Journal of Business Logistics, 17, 2, 35-55.

Granovetter, M. (1985). Economic action and social structure: The problem of embeddedness. American Journal of Sociology, 91, 481-510.

Heide, J. B. (1994). Interorganizational governance in marketing channels. Journal of Marketing, 58, 71-85. 
Heide, J. B. \& John, G. (1990). Alliances in industrial purchasing: The determinants of joint action in buyer-supplier relationships. Journal of Marketing Research, 27 , 20-35.

Heide, J. B. \& Miner, A. S. (1992). The shadow of the future: Effects of anticipated interaction and frequency of contact on buyer-seller cooperation. Academy of Management Journal, 35, 265-291.

Hennart, J. (1993). Explaining the swollen middle: Why most transactions are a mix of market and hierarchy. Organization Science, 4, 529-547.

Hosmer, L. T. (1995). Trust: The connecting Jink between organizational theory and philosophical ethics. Academy of Management Review, 20, 379-403.

Kanneman, D. \& A. Tversky (1979). Prospect theory: An analysis of decision making under risk. Econometrica, 47, 262-291.

Kelly, H. H. \& Thibaut, J. W. (1959). The social psychology of groups. New York: Wiley.

Klein, B., Crawford, R. G., \& Alchian, A. A. (1978). Vertical integration, appropriable rents, and the competitive contracting process. Journal of Law and Economics, $21,297-326$.

MacCrimmon, K. R. \& Wehrung, D. A. (1986). Taking risks: The management of uncertainty. New York: Free Press.

Maltz, A. (1994). Outsourcing the warehouse function: Economic and strategic considerations. Logistics and Transportation Review, 30, 245-265.

March, J. G. \& Shapira, Z. (1992). Variable risk preferences and the focus of attention. Psychological Review, 99, 172-183.

Macneil, I. R. (1978). Contracts: Adjustments of long-term economic relations under classical, neoclassical, and relational contract law. Northwestern University Law Review, 72, 854-905.

Macneil, I. R. (1980). The new social contract: An inquiry into modern contractual relations. New Haven, CT: Yale University Press.

Masten, S. E., Meehan, J. W., \& Snyder, E. A. (1989). Vertical integration in the US auto industry: A note on the influence of transaction specific assets. Journal of Economic Behavior and Organization, 12, 265-273.

McWilliams, A. \& Gray, S. (1995). Understanding quasi-integration. Journal of Business Strategies, 12, 69-85. 
Monteverde, K. \& Teece, D. J. (1982). Supplier switching costs and vertical integration in the automobile industry. Bell Journal of Economics, 13, 206-213.

Noorderhaven, N. (1994). Transaction cost analysis and the explanation of hybrid vertical inter-firm relations. Review of Political Economy, 6, 19-36.

Nooteboom, B., H. Berger, H., \& Noorderhaven, N. G. (1997). Effects of trust and governance on relational risk. Academy of Management Journal, 40, 308-338.

Ouchi, W. G. (1980). Markets, bureaucracies and clans. Administrative Science Quarterly, 25, 129-141.

Parkhe, A. (1993). Strategic alliance structuring: A game theoretic and transaction cost examination of interfirm cooperation. Academy of Management Journal, 36, 794- 829 .

Pratten, S. (1997). The nature of transaction cost economics. Journal of Economic Issues, 31, 781-803.

Ring, P. S. \& Van de Ven, A. (1992). Structuring cooperative relationships between organizations. Strategic Management Journal, 13, 483-498.

Ring, P. S. \& Van de Ven, A. (1994). Developmental processes of cooperative interorganizational relationships. Academy of Management Review, 19, 90-118.

Robins, J. A., (1987). Organizational Economics: Notes on the use of transaction cost theory in the study of organizations. Administrative Science Quarterly, 32, 68-86.

Simon, H. A. (1961). Administrative behavior, (2nd ed.). New York: Macmillan.

Sitkin, S. B. \& Pablo, A. L. ( 1992). Reconceptualizing the determinants of risk behavior. Academy of Management Review, 17, 9-38.

Sitkin, S. B. \& Weingart, L. R. (1995). Determinants of risky decision-making behavior: A test of risk perceptions and propensity. Academy of Management Journal, 38, 1573-1592.

Tversky, A. \& Kahneman, D. (1992). Advances in prospect theory: Cumulative representation of uncertainty. Journal of Risk and Uncertainty, 5, 297-323.

Tyler, T. R. \& Degoey, P. (1996). Trust in organizational authorities: The influence of motive attributions on willingness to accept decisions. In R. M. Kramer \& T.R. Tyler (Eds.) Trust in organizations, (pp. 331-356). Thousand Oaks, CA: Sage.

Van de Ven, A. H., Venkatraman, S., Polley, D., \& Garud, R. (1989). Processes of new business creation in different organizational settings. In A, Van de Ven, H. Angle, $\&$ M. S. Poole (Eds.) Research on the management of innovation: The Minnesota studies, (pp. 221-298). New York: Ballinger/Harper \& Row. 
Van de Ven, A. H. \& Walker, G. (1984). The dynamics of interorganizational coordination. Administrative Science Quarterly, 29, 598-621.

Venkatraman, N. \& Christiaanse, E. (1996). Electronic channels for expertise exploitation: An empirical test of airline-travel agency relationships, Academy of Management Proceedings, Cincinnati, $\mathrm{OH}$.

Walker, G. \& Weber, D. (1984). A transaction cost approach to make-or-buy decisions. Administrative Science Quarterly, 29, 373-391.

Williamson, O. E. (1975). Markets and hierarchies: Analysis and antitrust implications. New York: Free Press.

Williamson, O. E. (1985). The economic institutions of capitalism: Firms, markets, relational contracting. New York: Free Press.

Williamson, O. E. (1991). Strategizing, economizing and economic organization. Strategic Management Journal, $12,75-94$.

Williamson, O. E. (1993). Calculativeness, trust, and economic organization. Journal of Law and Economics, 36, 453-486.

Williamson, O. E. (1999). Strategy research: Governance and competence perspectives. Strategic Management Journal, 20, 1087-1108.

Zaheer, A. \& Venkatraman, N. (1994). Determinants of electronic integration in the insurance industry: An empirical test. Management Science, 40, 5, 549-566.

Zaheer, A.\& Venkatraman, N. (1995). Relational governance as an interorganizational strategy: An empirical test of the role of trust in economic exchange. Strategic Management Journal, 16, 373-392.

John K. Masters is Associate Professor of Management at Louisiana State University in Shreveport. He earned his Ph. D. at the University of North Texas. His research interests include organization-environment relationships and the blurring of organizational boundaries. His research has been published in the Academy of Management Journal, the Journal of Business Ethics and other leading outlets.

Grant Miles is Associate Professor of Management in the College of Business Administration at the University of North Texas. He received his Ph.D. from The Pennsylvania State University. His research interests are linked around a primary focus on organizational adaptation and the role of knowledge, learning and collaboration in this process. His research has been published in a number 
of top academic and practitioner outlets including the Academy of Management Journal, Strategic Management Journal, and California Management Review.

Dr. Derrick E. D'Souza is Associate Professor of Management at the University of North Texas and is President at Executive Renewal, an OD consulting firm. He consults, researches and teaches in the areas of strategic business integration, organizational architecture, operations flexibility and international business. He has published widely in both academic and practitioner journals, and is co-author of A Toolbook for Strategic Business Integration, 4 th ed. He can be reached at dsouza@unt.edu.

John Patrick Orr earned his Ph.D. from the University of North Texas in Organization Theory \& Policy. He is currently Assistant Professor of Management at McKendree College in Lebanon, Illinois. His teaching interests include business ethics, operations management, strategy, and international business; also, he has taught in both Western Europe and Russia. Dr. Orr researches trust, governance, and cross-cultural issues in strategic alliances, with a focus on logistics alliances.

\section{Footnotes}

${ }^{1}$ The authors wish to thank John Beard and several anonymous reviewers for their comments on an earlier version of this paper presented at the 2000 annual meeting of the South West Academy of Management 
